\title{
Identification of Heavy Metal in Palm Oil Empty Fruit Bunch Compost, Mulch from Palm Oil Waste and Its Effect on Chili (Capsicum annuum L.)
}

\author{
Mercy Bientri Yunindanova ${ }^{1^{*}}$, Herdhata Agusta $^{2}$, Dwi Asmono $^{3}$ \\ ${ }^{1}$ Dep. of Agrotechnology, Faculty of Agriculture, Sebelas Maret University, Surakarta, Indonesia \\ ${ }^{2}$ Dep. of Agronomy and Horticulture, Faculty of Agriculture, \\ Bogor Agricultural University, Indonesia \\ ${ }^{3}$ PT Sampoerna Agro Tbk, Palembang, Indonesia \\ *Corresponding author: mercybientri@gmail.com
}

Received: 12 June 2015, Revised: 30 September 2016, Accepted: 10 April 2016

\begin{abstract}
This study aimed to investigate the effect of compost from oil palm empty fruit bunches with different ages, mulching oil palm waste, the levels of heavy metals in compost and its influence on the growth and yield of chili. Composting was assisted by the starter (Promi ${ }^{\mathrm{TM}}$ ) with a dose of $0.5 \mathrm{~kg}$ per ton of chopped bunches. Composting treatment distinguished by the composting time namely 4, 6, 8 and 10 weeks. Mulch treatment consisted of shell, fiber and empty fruit bunch chopped. The empty fruit bunch compost had the potential to decrease the soil acidity because the $\mathrm{pH}$ of 7.89- 8.66. The EFBs compost contained Boron of 7.7-10.7 ppm, 12-24.8 ppm of Cuprum, 0.05 to $0.24 \%$ of $\mathrm{Fe}, 26.5-89.7 \mathrm{ppm}$ of $\mathrm{Mn}$, and 9.1-10.8 ppm of $\mathrm{Na}$. This compost contained heavy metal $\mathrm{Cd}$ and $\mathrm{Hg}$. $\mathrm{Cd}$ was detected in amount of 0.08 to $0.25 \mathrm{ppm}$. $\mathrm{Hg}$ was detected in amount of 12.9-19.5 ppm. Meanwhile, $\mathrm{Pb}$ and $\mathrm{As}$ were not found. $\mathrm{Cd}$ did not exceed the threshold. On the other hand, $\mathrm{Hg}$ was detected exceeding the threshold but did not affect the growth and yield of chili. Organic mulch from palm oil wastes did not significantly affect on the chili yield. Shell mulch had a negative influence on the growth and yield of chili.
\end{abstract}

Keywords: heavy metal, compost, empty fruit bunch, chili

\section{INTRODUCTION}

During the extraction process, palm oil generates by-products and wastes known as empty fruit bunch (EFBs), palm oil mill effluent (POME), sterilizer condensate, palm pressed fibre and palm kernel shell (Yusoff, 2006). The major biomass byproduct from the oil palm industry is empty fruit bunch (EFBs). Empty fruit bunch is $22 \%$ of FFB or $4.42 \mathrm{mt} /$ ha/year. Shell is $5.5 \%$ from FFB or $1.10 \mathrm{mt} / \mathrm{ha} /$ year and palm pressed fibre is $13.5 \%$ from FFB or $2.71 \mathrm{mt} /$ ha/year (Yusoff, 2006). Palm pressed fibre (PPF) is a by-product after screw-pressing of palm fruits during production of CPO. The abundance of palm pressed fibre (PPF) biomass waste generates greenhouse gases (Hafis, 2014).

This biomass waste has been utilized to generate energy and electrical to support the mill process. The fiber and shell are also burnt to generate steam for downstream processes that required steam such as sterilization. At the same time, using the fiber and shell as boiler fuel can help to dispose these bulky materials which can contribute to environmental pollution (Ismail et al., 2012). Composting is one of the most effective ways for recycling of organic solid waste (Huang et al 2003). Since oil palm by-product decomposes slowly under normal condition, soil micro- and macro-organisms are required to enhance the decomposition process (Rupani et al., 2013).

The palm oil industry is currently expanding rapidly and produces large amounts of poorly utilized waste biomass (Abdullah et al, 2011). Therefore, an investigation of utilization of palm oil waste outside the palm oil plant is worthwhile. Research on the composting of 
palm oil has been widely reported. However, the use in plant cultivation is still limited to the cultivation of palm oil. Fiber and shells have not been widely reported use in the field of horticulture. Assessment of heavy metals in EFBs compost is also indispensable relation to its use in plant cultivation. Thus, this study aimed to investigate the effect of compost from EFBs with different ages, mulching oil palm waste, the levels of heavy metals and its influence on the growth and yield of chili. Chili plant as a model because this plant is much needed by local communities and most widely cultivated on a domestic scale household.

\section{MATERIALS AND METHODS \\ Composting}

Composting was conducted in palm oil processing plant PT Mutiara Bunda Jaya, South Sumatra, Indonesia. It was assisted by the starter Promi ${ }^{\mathrm{TM}}$ (a dose of $0.5 \mathrm{~kg} /$ ton of chopped bunch). This treatment distinguished by the time namely 4, 6, 8 and 10 weeks.

\section{Chili Planting}

This study used ultisol soil that has low $\mathrm{pH}$ of 4.64 with CEC of $7.04 \mathrm{mEq} / 100 \mathrm{~g}$. First, growing medias were given Rock Phosphat $\left(\mathrm{Ca}_{3}\left(\mathrm{PO}_{4}\right)_{2}\right)$ of $20 \mathrm{~g} /$ polybag. The compost was applied by mixing soil and compost in the ratio $2: 1(\mathrm{v} / \mathrm{v})$. Urea and muriate of potash (MOP) were applied $5 \mathrm{~g} /$ plant and $10 \mathrm{~g} /$ plant, respectively.

\section{Mulching}

Three mulching treatments namely chopped EFBs, fiber and shell along with a control (bare soil) were imposed on chilli by surface application. Installation of mulch was made in a thickness of 3-5 cm. Installation of mulch was performed 1 week after planting. Shell mulch was 200 grams weigh and 100 grams for fiber and EFBs chopped.

\section{Compost Analysis}

The analysis consisted of compost temperature ( $1^{\text {st }}$ week to $10^{\text {th }}$ week), organic carbon, $\mathrm{pH}$ (using a pH meter (Model: HANNA HI 8520)), micronutrient analysis such as $\mathrm{Na}, \mathrm{Fe}, \mathrm{Mn}, \mathrm{B}$, and $\mathrm{Cu}$ and heavy metal analysis ( $\mathrm{Pb}, \mathrm{Cd}, \mathrm{Hg}$ dan $\mathrm{As}$ ) were analyzed by Atomic Absorption Spectrophotometer (AAS) (Elmer,2000).

\section{Data collected and Statictic Analysis}

Vegetative data covered plant heigh, stem diameter, and number of leaves per plant every week from 1 week after planting to 12 weeks. To get dry basis, the plant was oved-dried at $60^{\circ} \mathrm{C}$ for 1 day. For root analysis (root length, root volume, root fresh weigh and root dry weigh) each plant was carefully uprooted and the roots were gently washed with water to remove the soil. Numbers of fruits per plant and fruit yield per plant were recorded at final harvest. The experiment was arranged in Split Plot Design (RCBD) with three replications. Data was analyzed using SPSS version 16 (SPSS, 2005). Duncan's Multiple Range Test (DMRT) was performed to separate means. Statistics for all main effects were compared using analysis of variance (Anova).

\section{RESULTS}

\section{Evaluation of Compost Physico-Chemical Properties \\ Compost Temperature}

Temperature is suggested to be one of the most convenient parameters for stability evaluation (Huang et al. 2003). Temperature is also one of the key factors affecting the composting process. Compost heat is produced as a by-product of microbial breakdown of organic matter (Nagasaki et al., 1985; Venglovsky et al., 2005). The heat production depends on the size of the pile, its moisture 
content, aeration, and the $\mathrm{C} / \mathrm{N}$ ration of starting materials.

The result (Figure.1) showed that the initial temperature of the composting process in the first week is $62.93^{\circ} \mathrm{C}$. In the second week, temperatures rose rapidly up to $66.13^{\circ} \mathrm{C}$, then the rate slowed down. A maximum of $67.53^{\circ} \mathrm{C}$ was reached in the forth week. After maximum level, temperatures again decreased up to $63.87^{\circ} \mathrm{C}$. Temperature composting at fifth week to ninth week fluctuated in the range of 64.00 to 62.73 . In the end, the temperatures fall down to $59.27^{\circ} \mathrm{C}$. In this case, a slight final drop was observed; this could have been near to the end of the composting process, since after the last turning the maximum values were not regained (Canet \& Pomares 1995).

The maximum temperature was $67.53^{\circ} \mathrm{C}$ in the $4^{\text {th }}$ week. This temperature was lower than the composting process of municipal solid wastes by Canet and Pomares (1995), which reach up to $75^{\circ} \mathrm{C}$. In this phase, the compost pile undergone "thermophilic phase". In general, the highest microbial numbers and enzimatic activities occur during this phase (Cunha-Queda et al. 2007). The increase of temperature that causes significant changes in the microbial communities (Hassen et al. 2001; Sundh and Ronn, 2002) is essensial for the autosterilization of the compost. The rise and fall of temperature has been reported to be correlated with microbial properties (Epstein 1997). Significant positive correlations are found between temperature and microbial properties such as $\mathrm{O}_{2}$ consumption rate, ATP content, dehydrogenase activity and microbial biomass $\mathrm{N}$. This result showed that the rise and fall of temperature was paralleled with the changes of these four microbial properties (Tiquia 2005).

\section{Organic Carbon (OC)}

Carbon component is one of the indicators of compost value. The total OC is an indicator of its organic matter concentration (Stoffella and Kahn 2001). OC provides a direct estimate of the biologically degradable carbon in the compost. During composting carbon is transformed into more complex compounds such as humus and mineralized and lost as carbon dioxide $\left(\mathrm{CO}_{2}\right)$. The total OC in compost includes forms of organic matter at different stages of degradation, some resistant to further decomposition and some remaining biologically active (California Compos Quality Council 2001).

The results showed that the level of OC in the fourth week was $48.9 \%$. The OC declined at the sixth week to $46.2 \%$. At the eigth week to the tenth, the OC content increased gradually up to

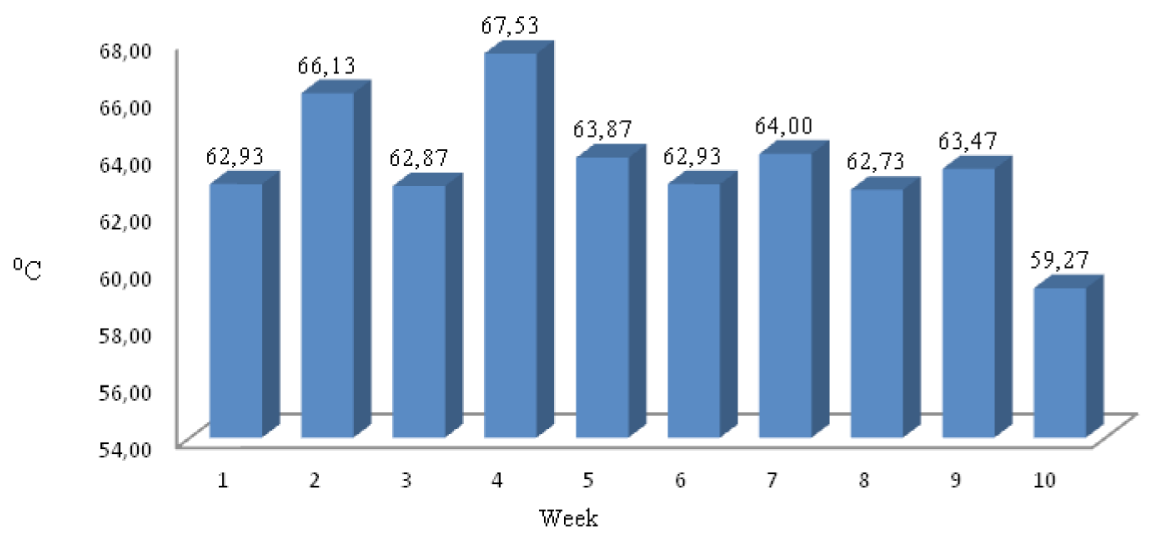

Figure 1. Compost temperature changes during decomposition 
$50.03 \%$ at tenth week.This result was different from previous research by Huang et al. (2006) by which total OC of the compost decreases rapidly from $45 \%$ to $36 \%$ at 14 days after composting process initiation. It is followed by a gradual decrease to below $35 \%$ after 49 days showing an overall loss of $10 \%$ of OC.

The total OC depends on organic content of the raw materials. Samples of compost with the highest values of organic matter (above 50\%) had total OC concentrations of approximately 30\% (Montejo et al. 2015). Compost from other raw materials such as pig manure and Populus sp. wood chips (Vázquez et al., 2015) produces total OC of 25.1-34.8\% with organic carbon value before composting in range of $38.12-45.74 \%$. This indicated that the levels of OC from EFBs compost had particularly higher value.

Total OC decline also accured in Francou et al. (2005) and Tiquia (2005) which stated that for all composts, total OC mineralization decreases when the duration of composting increased due to the stabilization of the organic matter during the composting process. However, increased levels of total $\mathrm{OC}$ in the addition of composting time also occurs in treatment Green Waste 2, by which the levels of total OC in third month is $27.9 \%$, decreases in the fourth

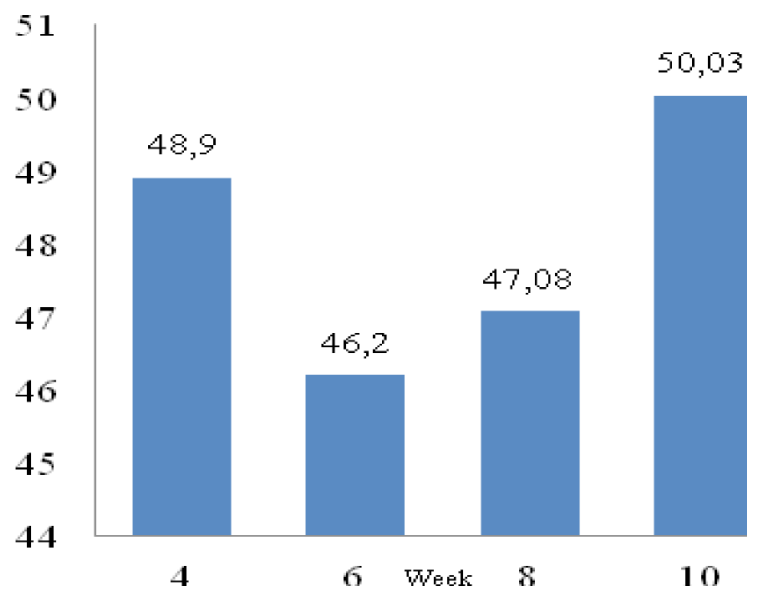

Figure 2. Changes in levels of organic carbon in the composting process month up to $19.6 \%$ and rises in sixth month to $22.3 \%$. The same things happen in the treatment of biowastes by which in the third month total OC is $16.6 \%$, declines in the fourth month up to $15.5 \%$ and enhances in the sixth month to be 18.8\% (Francou et al. 2005).

\section{pH Value}

In the fourth week (Figure 3.) the $\mathrm{pH}$ of compost was 8.21. In the sixth week the $\mathrm{pH}$ increased significantly to 8.66 followed by a decrease until 8.58 at week 8. Finally, pH reached the value of 7.89 in the tenth week.

Similar results were shown in study by Irshad et al. (2013) with compost made from manure. The $\mathrm{pH}$ of the finished compost ranges between 8.20 and 9.34 (Kumar et al., 2007). The acceptable range of $\mathrm{pH}$ at the end of composting is 7.5 to 8.0 regardless of beginning $\mathrm{pH}$ (USDANRCS. 2000). As the decomposition proceeded, the $\mathrm{pH}$ value gradually increase up to 8.0 , while the final value is recorded as 7.0, indicating the stability of organic matter (Pan and Sen 2013).

The increase of $\mathrm{pH}$ is generally thought to be the result of volatilization and microbial decomposition of the organic acids and subsequent release of ammonia through mineralization of organic nitrogen sources

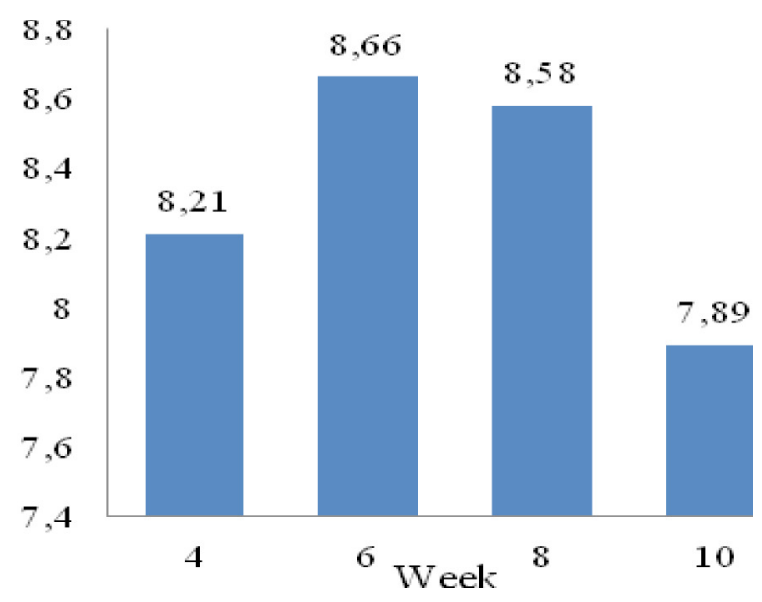

Figure 3. Changes in $\mathrm{pH}$ levels in the composting Process 
(Mckinley and Vestal 1985). Earlier studies have indicated that $\mathrm{pH}$ range of $5.5-9.0$ is suitable for microbial decomposition of organic materials, while the composting process is most effective at $\mathrm{pH}$ values between 6.5 and 8.0 (Pan et al., 2012). In the end of composting, $\mathrm{pH}$ reduce significantly. This decrease in $\mathrm{pH}$ could be attributed to the modified chemical composition through microbial action, notably the production of organic acids (Irshad, et al., 2013). Also, higher mineralization of nitrogen and phosphorus into nitrites/nitrates and orthophosphate causes the lower $\mathrm{pH}$ (Ndegwa et al., 2000).

\section{Microelement}

$\mathrm{Na}$ was recorded from $9.1 \mathrm{ppm}$ to 10.8 ppm. Fe was detected from $0.05 \%$ to $0.24 \%$ or 500 ppm to $2400 \mathrm{ppm}$ while Na was recorded of $9.1 \mathrm{ppm}$ to $10.8 \mathrm{ppm}$. The highest $\mathrm{Mn}$ content was 4 weeks compost of $78 \mathrm{ppm}$. In contrast, the lowest Mn content was 10 weeks compost of $26.5 \mathrm{ppm}$. Boron had range from 7.7 to 10.7 ppm. Compost 8 weeks had the highest $\mathrm{Cu}$ content of $24.8 \mathrm{ppm}$ while 10 weeks compost had the lowest $\mathrm{Cu}$ content.

Table1. Microelement in EFBs compost

\begin{tabular}{cccccc}
\hline $\begin{array}{c}\text { Compost } \\
\text { Age }\end{array}$ & $\begin{array}{c}\mathrm{Na} \\
(\mathrm{ppm})\end{array}$ & $\mathrm{Fe}(\%)$ & $\begin{array}{c}\mathrm{Mn} \\
(\mathrm{ppm})\end{array}$ & $\begin{array}{c}\mathrm{B} \\
(\mathrm{ppm})\end{array}$ & $\begin{array}{c}\mathrm{Cu} \\
(\mathrm{ppm})\end{array}$ \\
\hline 4 weeks & 10.8 & 0.15 & 78 & 8.4 & 19.5 \\
6 weeks & 9.1 & 0.09 & 60.4 & 8.7 & 15.8 \\
8 weeks & 9.2 & 0.24 & 89.7 & 10.7 & 24.8 \\
10 weeks & 9.1 & 0.05 & 26.5 & 7.7 & 12 \\
\hline
\end{tabular}

In general, micronutrient had no correlation with the compost age. Increasing age did not affect the increase or decrease of micronutrients. This result was different from Canet and Pomares (1995) that stated that compost from municipal solid waste produces Fe of 16958 and7340 ppm, Mn of 207 and $138 \mathrm{ppm}, \mathrm{Cu}$ of 496 and $200 \mathrm{ppm}$. Compost from sewage sludge from a waste-water treatment facility (Casadovela et al. 2006) contains Fe of 1602 ppm, Mn of $117 \mathrm{ppm}$, Boron of $87 \mathrm{ppm}, \mathrm{Na}$ of $570 \mathrm{ppm}$, and $\mathrm{Cu} 26.2 \mathrm{ppm}$. It means that compost from EFBs contained lower $\mathrm{Fe}$ than those from municipal solid waste but higher than those from sewage sludge. $\mathrm{Na}, \mathrm{Mn}, \mathrm{B}$ and $\mathrm{Cu}$ from EFBs compost were lower than those from sewage sludge.

The micronutrient in EFBs compost was generated from fresh $\mathrm{EFB}$ which contains $\mathrm{Na}$ of $3300 \mathrm{ppm}, \mathrm{Fe}$ of $2900 \mathrm{ppm}, \mathrm{Ca}$ of 14300 ppm, Mg of 1900 ppm, K of 86100 ppm, P of $10600 \mathrm{ppm}$ and Si of $19500 \mathrm{ppm}$ (Jensen et al., 1998). Indonesia Standars of Compost (SNI 19-7030-2004) of compost spesification from organic domestic waste states maxmimum $\mathrm{Fe}$ is $2 \%, \mathrm{Cu}$ maxmimum is $100 \mathrm{mg} / \mathrm{kg}$, and $\mathrm{Mn}$ maxmimum is $0.1 \%$. German standard (Krauss \& Grammel, 1992) stated that $\mathrm{Cu}$ maxmimum is $150 \mathrm{mg} / \mathrm{kg}$. It means that compost from EFBs was still safe for their micronutrients.

\section{Heavy Metal}

Heavy metals were detected in EFBs compost. Cd levels found at 0.08 to $0.25 \mathrm{ppm}$. Furthermore, $\mathrm{Hg}$ was detected in amount of 12.9 from 4 weeks compost to 19.5 from 10 weeks compost. In contrast, $\mathrm{Pb}$ and As were not recorded in this study.

Table 2. Heavy metal content (ppm) from EFBs compost

\begin{tabular}{ccccc}
\hline Compost Age & $\mathrm{Pb}$ & $\mathrm{Cd}$ & $\mathrm{Hg}$ & \multicolumn{2}{c}{ As } \\
\hline 4 weeks & nd & 0.21 & 12.9 & nd \\
6 weeks & nd & 0.25 & 19.4 & nd \\
8 weeks & nd & 0.08 & 13.0 & nd \\
10 weeks & nd & 0.08 & 19.5 & nd \\
\hline
\end{tabular}

nd : not detected

The composting process is affected by starting materials (feedstocks), decomposing organisms and environmental factors (Annabi et al., 2007; Farrell and Jones, 2009). Cd from 
Table 3. Number of leaves, stem diameter $(\mathrm{mm})$, root fresh weigh $(\mathrm{g})$, root dry weigh $(\mathrm{g})$, root volume $(\mathrm{mL})$, root lenght $(\mathrm{cm})$ on compost treatment

\begin{tabular}{lcccccc}
\hline Treatment & $\begin{array}{c}\text { Number of } \\
\text { Leaves }\end{array}$ & $\begin{array}{c}\text { Stem } \\
\text { Diameter }\end{array}$ & $\begin{array}{c}\text { Root Fresh } \\
\text { Weigh }\end{array}$ & $\begin{array}{c}\text { Root Dry } \\
\text { Weigh }\end{array}$ & $\begin{array}{c}\text { Root } \\
\text { Volume }\end{array}$ & $\begin{array}{c}\text { Root } \\
\text { Length }\end{array}$ \\
\hline Control (No compost) & 36.9 & $8.76^{\mathrm{a}}$ & $12.92^{\mathrm{ab}}$ & 3.47 & $12.36^{\mathrm{c}}$ & 27.23 \\
4 Weeks & 36.9 & $9.23^{\mathrm{ab}}$ & $10.14^{\mathrm{a}}$ & 3.55 & $9.58^{\mathrm{a}}$ & 26.31 \\
6 Weeks & 35.5 & $8.91^{\mathrm{a}}$ & $10.42^{\mathrm{a}}$ & 3.57 & $10.14^{\mathrm{ab}}$ & 25.93 \\
8 Weeks & 50.8 & $9.68^{\mathrm{b}}$ & $11.11^{\mathrm{ab}}$ & 3.87 & $11.39^{\mathrm{abc}}$ & 24.79 \\
10 Weeks & 32.9 & $9.48^{\mathrm{b}}$ & $13.61^{\mathrm{b}}$ & 4.20 & $13.47^{\mathrm{c}}$ & 25.35 \\
\hline
\end{tabular}

Note : Figures followed by the same letter are not significantly different at DMRT 5\%

this study was lower compared to Canet and Pomares (1995) which stated that Cd from municipal solid waste compost is in range of 2.9 to $6.2 \mathrm{ppm}$. In contrast, municipal solid waste compost detected $\mathrm{Pb}$ of 695 and 345 ppm.

Heavy metals in this EFBs compost might be due to the EFBs as raw material contains heavy metals from the plant tissue or from the surrounding while oil pressing or compost processing because of the influence of the tool. Setyorini et al. (2003) stated that heavy metal pollution may derive from the use of phosphate fertilizers. Phosphate fertilizers used in agriculture can lead to pollution of soil, because these fertilizers contain heavy metals. Lahuddin (2007) added that the fosforit rocks may contain 0-500 ppm of Cd. $\mathrm{Hg}$ contamination in the soil can be derived from the weathering process of mineralized rock. $\mathrm{Hg}$ is also found in inorganic fertilizers like TSP with levels of $0.0084 \mathrm{mg} / \mathrm{kg}, \mathrm{KCl}$ in amount of 0.0307 $\mathrm{mg} / \mathrm{kg}$ and Urea of $0.0003 \mathrm{mg} / \mathrm{kg}$ (Ershad et al., 2014).

The maximum value of $\mathrm{Hg}$ based on European standards ranges from $0.7-10 \mathrm{mg} / \mathrm{kg}$ depending on the respective countries. While the maximum $\mathrm{Hg}$ based on American standard is $17 \mathrm{mg} / \mathrm{kg}$. The maximum Cd based on European standards is $0.7-10 \mathrm{mg} / \mathrm{kg}$. The maximum $\mathrm{Cd}$ based on the American is $39 \mathrm{mg} / \mathrm{kg}$ (Brinton, 2000). Indonesian standard (SNI 19-7030-2004) of the specifications of compost from domestic organic waste states that the maximum value of $\mathrm{Hg}$ is $0.8 \mathrm{mg} / \mathrm{kg}$, Cd maximum is $3 \mathrm{mg} / \mathrm{kg}, \mathrm{Pb}$ maximum is $150 \mathrm{mg} / \mathrm{kg}$ and Arsen maximum is $13 \mathrm{mg} / \mathrm{kg}$. This showed that the Cd was below the threshold. Conversely, $\mathrm{Hg}$ has exceeded safe limits for compost.

\section{Effect on Chili}

\section{Compost Effect}

The compost did not significantly affect the number of leaves. The number of leaves produced ranged of 32.9-50.8/plant. This leaves number was smaller that those in Yanti et al. (2009) that stated the chili control plants recorded of 52 leaves, while the treatment of $P$. Fluorescens to chili is in amount of 59 leaves.

Table 4. Yield weight (g), number of fruit dan fruit weight $(\mathrm{g})$ on compost treatment

\begin{tabular}{llll}
\hline Treatment & $\begin{array}{l}\text { Yield } \\
\text { Weigh }\end{array}$ & $\begin{array}{l}\text { Number of } \\
\text { Fruit }\end{array}$ & $\begin{array}{l}\text { Fruit } \\
\text { Weight }\end{array}$ \\
\hline $\begin{array}{l}\text { Control (No } \\
\text { compost) }\end{array}$ & 48.96 & 42 & 1.17 \\
4 Weeks & 44.70 & 35 & 1.28 \\
6 Weeks & 36.25 & 31 & 1.18 \\
8 Weeks & 41.17 & 35 & 1.21 \\
10 Weeks & 44.99 & 38 & 1.17 \\
\hline
\end{tabular}

Note : Figures followed by the same letter are not significantly different at DMRT 5\%

Stem diameter was significantly influenced by compost. The highest stem diameter found on the 8 weeks compost of $9.68 \mathrm{~mm}$, but it was not significantly different from 10 weeks and 4 weeks compost. On the contrary, the lowest stem diameter was generated from control (no compost) of 8.76. Nevertheless, this result was 
lower than stem diameter by Arifin et al. (2014) in which chili stem diameter could reach 11.55 $13.89 \mathrm{~mm}$. It means that although the compost from EFBs contained heavy metal of $\mathrm{Cd}$ and $\mathrm{Hg}$, compost treatment proven to produce grater stem diameter than control (no compost). In other words, Cd value of 0.08-0.21 ppm did not give negative effect to chili stem diameter. Furthermore, the $\mathrm{Hg}$ value that higher than allowable limit did not give an adverse effect to the formation of chili stem diameter.

The compost significantly influenced the fresh weight of roots and root volume. In contrast, it did not have an effect on root dry weight and root length. The highest root fresh weight was $13.61 \mathrm{~g}$ from 10 weeks compost. However, the 10 weeks compost was not significatly different from 8 weeks compost and control (no compost). The root fresh weigh had positive correlation with root volume. Thus, the 10 weeks compost generated the highest root volume of $13.47 \mathrm{~g}$. This case confirmed that even though the content of $\mathrm{Hg}$ heavy metals in 10 weeks compost was the highest value (19.5 ppm), the compost was still capable of producing the highest root fresh weight. Therefore, the use of 10 weeks compost was not harmful to chili. The other reason for 10 weeks compost might be associated with high levels of OC. In addition, the compost 10 weeks had relatively small level of $\mathrm{Cd}(0.08 \mathrm{ppm})$. Among all heavy metals, $\mathrm{Cd}$ is a metal that is more easily accumulated by the plant compared with other heavy metal ions (Nopriani 2011). Research conducted by Susana and Suswati (2011) showed symptoms of chlorosis and stunted on Cd dosing at $32 \mathrm{mg} /$ $\mathrm{kg}$ on greens mustard and chinese cabbage. This suggests that the levels $\mathrm{Cd}$ at $0.08 \mathrm{ppm}$ was still in the low range.

Root length was not affected significantly by compost. However, root length was lower than those stated by Typhoon (2008) by which chili has a taproot, consisting of the main root and lateral roots that produce fibers and is able to penetrate into the soil up to $50 \mathrm{~cm}$ and up to $45 \mathrm{~cm}$ wide. The value of root fresh weigh and root volume were not significantly different from control (no compost), 8 weeks and 10 weeks compost migh be due to the application of compost in this study was one-third of media volume with incorporated method. In addition, it also showed that the content of heavy metals of $\mathrm{Cd}$ and $\mathrm{Hg}$ in the 8 weeks compost and 10 weeks compost were not detrimental to the development of the chili roots. The $\mathrm{Hg}$ did not disturb the root growt because of mixing applications with the soil so the overall availability of $\mathrm{Hg}$ becomes smaller.

The compost did not significantly affect chili yields, number of fruit and fruit weigh. The yield weight on control (no compost) and on the use of compost were not significantly different ranged from $36.25 \mathrm{~g}$ to $48.96 \mathrm{~g}$. Number of fruit varied from 31 to 42 fruits. Fruit weight ranged from $1.17 \mathrm{~g}$ to $1.28 \mathrm{~g}$. This showed that even though EFBs compost potentially increasing $\mathrm{pH}$ in acid soils, the use of EFBs compost has not been able to improve chili yield on ultisol soil. Additionally, correlation test recorded that the levels of $\mathrm{Hg}$ uncorrelated with chili harvest variables. According to Widyati (2011), the amount of metal uptake by plants depends on the age of the plant, the amount of metal in the soil and the length of time in which the plant is located on contaminated soil. Schulze et al., (2005) stated that heavy metals transport such as mercury often passes through the apoplast generally. Heavy metals such as $\mathrm{Cr}, \mathrm{Ni}, \mathrm{Cd}$ and $\mathrm{Pb}$ are detected in the compost from sewage sludge from a waste-water treatment facility. This compost contains $\mathrm{Cr}$ of $19.0 \mathrm{ppm}, \mathrm{Pb}$ of $15.6 \mathrm{ppm}$, and $\mathrm{Cd}$ of $3 \mathrm{ppm}$. However, $\mathrm{Mg}$ is not detected. This result is not affect the growth of B. oleracea (Casado-vela et al. 2006). 


\section{Mulch}

Mulching significantly influenced the number of leaves and stem diameter. Instead, mulch did not significantly affect root wet weight, root dry weight, root volume and root length. The highest number of leaves was found in chopped EFBs mulch (46.7 leaves). However, it was not significantly different from fiber and control (no mulch). In other hand, the lowest number of leaves was recorded from shell (23.9 leaves). The highest stem diameter was generated in the control $(9.49 \mathrm{~mm})$. However, this treatment was not significantly different with chopped EFB and fiber. In contrast, the lowest stem diameter was recorded on shell in the amount of $8.62 \mathrm{~mm}$.

Root volumes had a range of 10.11 to $12.44 \mathrm{~mL}$ and were not affected by mulch. Although not significant, as stem diameter and the number of leaves, the lowest root volume was performed in the shell (10.11) $\mathrm{mL}$. Furthermore, the unfavorable effect of shell was ilustrated in root dry weigh and root length. The root dry weigh ranged of 3.33-4.13 g. The lowest root dry was $3.33 \mathrm{~g}$ in weigh from shell. At the same time, the lowest root was 24.18 $\mathrm{cm}$ in lengh from shell mulch. It explained that shell mulch also gave undesirable condition to root elongation.

Mulch did not significantly affect crop harvest variables. Chili harvest weights resulting from the use of mulch ranged from 39.97-46.23 g. But the highest was produced from control (no mulch) of $46.23 \mathrm{~g}$. On the contrary, the lowest harvest was $39.97 \mathrm{~g}$ in weigh from shell. These results were lower than those in Arifin et al. (2014) of $206.7 \mathrm{~g}$ to $667.0 \mathrm{~g}$. In addition, the number of fruit was not significantly affected by mulch. As shown in Table 6, the highest number of fruit/plant recorded on control (no mulch) (40 fruits). Conversely, the lowest number of fruit was performed on shell (34 fruits). The fruits were 1.17 to $1.23 \mathrm{~g}$ in weigh and were not influenced significantly by mulch. These fruit weight were smaller than those of Arifin et al. (2014), which reachs 3.34 to $13.37 \mathrm{~g}$ in weigh. Shell indicated a negative effect on the harvest variable. It could not conserve the enough soil moisture; create suitable soil temperature as well as suitable microclimate condition.

The control (no mulch) showed higher results than other was probably caused by the negative effects arising from oil palm waste mulch for 12 weeks. Fiber contains 31.84\% of water, carbon of $47.2 \%$, hydrogen of $6 \%$, and $1.4 \%$ of nitrogen. Shell contains $12 \%$ of water, carbon of $52.4 \%$, hydrogen of $6.3 \%$, and $0.6 \%$ of nitrogen (Ismail et al., 2012). It has been shown that the oil-palm shell has $55.7 \%$ of carbon content compared to oilpalm fibers $(49.6 \%)$, coffee shells $(50.3 \%)$, and sugar cane bagasse (53.1\%) (Rincon and Gomez, 2012). In the field, shells produced a higher surface temperature, thereby reducing soil moisture. This contrasts with the effect of mulch in general that should be able to lower the

Tabel 5. Number of leaves, stem diameter (mm), root fresh weigh $(\mathrm{g})$, root dry weigh $(\mathrm{g})$, root volume (mL), root lengh $(\mathrm{cm})$ in mulch treatment

\begin{tabular}{|c|c|c|c|c|c|c|}
\hline Treatment & $\begin{array}{c}\text { Number of } \\
\text { Leaves }\end{array}$ & Stem Diameter & $\begin{array}{c}\text { Root Fresh } \\
\text { Weigh }\end{array}$ & $\begin{array}{l}\text { Root Dry } \\
\text { Weigh }\end{array}$ & Root Volume & $\begin{array}{l}\text { Root } \\
\text { Lengh }\end{array}$ \\
\hline $\begin{array}{l}\text { Control (No } \\
\text { mulch) }\end{array}$ & $43.9^{b}$ & $9.49^{b}$ & 10.67 & 4.13 & 11.44 & 26.03 \\
\hline Shell & $23.9^{\mathrm{a}}$ & $8.62^{\mathrm{a}}$ & 10.78 & 3.33 & 10.11 & 24.18 \\
\hline Fiber & $39.9^{b}$ & $9.36^{\mathrm{b}}$ & 12.89 & 3.97 & 12.44 & 25.47 \\
\hline Chopped EFB & $46.7^{\mathrm{b}}$ & $9.36^{\mathrm{b}}$ & 12.22 & 3.50 & 11.56 & 28.00 \\
\hline
\end{tabular}

Note : Figures followed by the same letter are not significantly different at DMRT 5\% 
Table 6. Harvest weight (g), number of fruit and fruit weigh $(\mathrm{g})$ in mulch

\begin{tabular}{lccc}
\hline \multicolumn{1}{c}{ Treatment } & $\begin{array}{c}\text { Harvest } \\
\text { Weight }\end{array}$ & $\begin{array}{c}\text { Number } \\
\text { of Fruit }\end{array}$ & $\begin{array}{c}\text { Fruit } \\
\text { Weigh }\end{array}$ \\
\hline Control (No Mulch) & 46.23 & 40 & 1.17 \\
Shell & 39.97 & 34 & 1.19 \\
Fiber & 43.10 & 36 & 1.21 \\
Chopped EFB & 43.56 & 36 & 1.23 \\
\hline
\end{tabular}

temperature of the soil surface. This condition due to oil palm shell contains silica which has properties in moisture absorbing. Silica $\left(\mathrm{SiO}_{2}\right)$ on oil palm shell is $61 \%$ (IPRI 2010). This study was in contrast with previous research that stated that organic mulches significantly decrease soil temperature (Sinkevičienè et al., 2009). The character of the organic mulch which can lower soil temperature is largely determined by the type of material contained in the mulch. Meanwhile, fiber and fresh empry fruit bunch invited the arrival of the ants to the surrounding plant. This was probably due to the application of fresh fiber and chopped EFBs fresh still contained oil after extraction process. The negative influence of organic mulch is also likely due to the absorption of nitrogen from the media. The adverse effect of organic mulch is by drying up soil nitrogen due to a wide $\mathrm{C}: \mathrm{N}$ ratio (straw, peat, sawdust) (Johnson et al., 2004; Sønsteby et al., 2004).

\section{Interaction of Compost and Mulch}

The results demonstrated that the interaction of compost and mulching significantly affect the plant height. The highest plant $(58.35 \mathrm{~cm})$ was recorded from the combination of 10 weeks compost and control (no mulch). The lowest plant was produced from the combination of control (no compost) and shells mulch. This plant was lower than those in the use of chicken manure which reach a height of about 64.22 $\mathrm{cm}$ and the use of manure crickets which reach $65.68 \mathrm{~cm}$ in height (Andayani and Srido, 2013). Chili plant can reach a height of about 125.98 $\mathrm{cm}$ (Arifin et al., 2014). This result might be associated with interaction of 10 weeks compost that produced high root fresh weight and root volume (Table 3 ) and control (no mulch). As explained in the mulch effect, the highest harvest weigh also resulted from control (no mulch).

The similar results were seen in the plant canopy diameter. The highest plant diameter was recorded from combination of the 10 weeks compost and control (no mulch). The highest canopy diameter reached $47.03 \mathrm{~cm}$. Conversely, the lowest canopy diameter produced from the combination of (1) control (no compost) and shell, (2) the 6 weeks compost and shell and (3) the 10 weeks compost and shell. From these combinations, it appeared that shell combinations caused a decrease in canopy diameter. The lowest canopy diameter reached $36.99,37.90$ and $37.94 \mathrm{~cm}$ respectively. These performances were lower than the canopy diameter of chili resistant in acid soil (55.93$70.13 \mathrm{~cm}$ ) (Arifin et al., 2014). It was proved that either alone or in combination with other factors, shell always gave a bad influence on the growth of chili.

Table 7. Plants heigh $(\mathrm{cm})$ in combination of compost and mulch

\begin{tabular}{lllll}
\hline \multicolumn{1}{c}{ Compost Age } & \multicolumn{1}{c}{ Control (No Mulch) } & \multicolumn{1}{c}{ Shell } & \multicolumn{1}{c}{ Fiber } & \multicolumn{1}{c}{ Chopped of EFB } \\
\hline Control (No compost) & $50.10^{\text {bcdef }}$ & $45.07^{\text {a }}$ & $52.17^{\text {bcdefg }}$ & $52.78^{\text {bcdefg }}$ \\
4 weeks & $54.62^{\text {efgh }}$ & $49.24^{\text {abc }}$ & $55.03^{\text {fgh }}$ & $52.01^{\text {bcdefg }}$ \\
6 weeks & $55.31^{\text {gh }}$ & $49.39^{\text {abcd }}$ & $52.59^{\text {bcdefg }}$ & $53.13^{\text {bcdefg }}$ \\
8 weeks & $55.32^{\text {gh }}$ & $56.13^{\text {gh }}$ & $48.58^{\text {ab }}$ & $54.55^{\text {defgh }}$ \\
10 weeks & $58.35^{\text {h }}$ & $49.56^{\text {abcde }}$ & $54.17^{\text {cdefgh }}$ & $53.37^{\text {bcdefgh }}$ \\
\hline
\end{tabular}

Note : Figures followed by the same letter are not significantly different at DMRT 5\% 
Table 8. Plant canopy diameter $(\mathrm{cm})$ in combination of compost and mulch

\begin{tabular}{lcccc}
\hline Compost Age & Control (No Mulch) & Shell & Fiber & Chopped EFB \\
\hline Control (No compost) & $45.19^{\text {bcde }}$ & $36.99^{\mathrm{a}}$ & $44.54^{\mathrm{bcde}}$ & $45.09^{\mathrm{bcde}}$ \\
4 weeks & $45.69^{\mathrm{cde}}$ & $39.64^{\mathrm{ab}}$ & $45.08^{\mathrm{bcde}}$ & $40.49^{\mathrm{abcd}}$ \\
6 weeks & $43.95^{\mathrm{bcde}}$ & $37.90^{\mathrm{a}}$ & $39.98^{\mathrm{abc}}$ & $41.49^{\mathrm{abcde}}$ \\
8 weeks & $46.43^{\mathrm{e}}$ & $46.22^{\mathrm{de}}$ & $39.92^{\mathrm{abc}}$ & $40.31^{\mathrm{abc}}$ \\
10 weeks & $47.03^{\mathrm{e}}$ & $37.94^{\mathrm{a}}$ & $44.80^{\mathrm{bcde}}$ & $41.69^{\mathrm{abcde}}$ \\
\hline
\end{tabular}

Note : Figures followed by the same letter are not significantly different at DMRT 5\%

Table 9. Plant dry weigh (g) in combination of compost and mulch

\begin{tabular}{lcccc}
\hline Compost Age & Control (No Mulch) & Shell & Fiber & Chopped EFB \\
\hline Control (No compost) & $15.60^{\mathrm{ab}}$ & $13.77^{\mathrm{a}}$ & $19.23^{\mathrm{bcd}}$ & $19.73^{\mathrm{bcd}}$ \\
4 weeks & $17.43^{\mathrm{abc}}$ & $14.13^{\mathrm{a}}$ & $15.93^{\mathrm{ab}}$ & $16.07^{\mathrm{ab}}$ \\
6 weeks & $22.73^{\mathrm{d}}$ & $13.87^{\mathrm{a}}$ & $13.87^{\mathrm{a}}$ & $15.87^{\mathrm{ab}}$ \\
8 weeks & $20.87^{\mathrm{cd}}$ & $21.40^{\mathrm{cd}}$ & $15.90^{\mathrm{ab}}$ & $19.57^{\mathrm{bcd}}$ \\
10 weeks & $27.07^{\mathrm{e}}$ & $19.30^{\mathrm{bcd}}$ & $20.93^{\mathrm{cd}}$ & $21.80^{\text {cd }}$ \\
\hline
\end{tabular}

Note : Figures followed by the same letter are not significantly different at DMRT 5\%

Plant dry weight was also positively correlated with plant height and canopy diameter. The highest plant dry weight was recorded from the combination of 10 weeks compost and control (no mulch) $(27.07 \mathrm{~g})$. On the other hand, the lowest value were seen from four combinations namely (1) control (no compost) and shell (13.77 g), (2) 4 weeks compost and shell (14.13 g), (3) 6 weeks compost and shell (13.87 g) and (4) 6 weeks compost and fiber $(13.87 \mathrm{~g})$. From the four lowest combinations, it figured that the use of shell mulch situated in three combinations. This confirmed again the negative influence of the shell in combination with other factor.

\section{CONCLUSION}

It could be concluded that heavy metals $\mathrm{Hg}$ and $\mathrm{Cd}$ on the compost were not negatively affect plant growth. This was because of its used in small amounts and mixed with the soil. Decrease in performance and production of chili more due to the soil type ultisol. The use of organic mulch of solid waste palm oil did not affect on the growth and yield of chili. Shell mulch suppressed the growth of chili and thereby, decreased the fruits yield of chili for 4 months. Therefore, the shell was not recommended for use as mulch on horticultural crops.

\section{ACKNOWLEDGEMENT}

The authors would like to acknowledge and thank PT Sampoerna Agro Tbk. for fully funding the research described in this publication. My sincere thanks also go to Mr.Saiful Rhodian Ahmad and Mr. Gatot Abdul Rahim for their encouragement.

\section{REFERENCES}

Andayani \& Sarido, L. (2013). Uji empat jenis pupuk kandang terhadap pertumbuhan dan hasil tanaman cabai keriting (Capsicum annum L.) (Investigation of four types of manure to the growth and yields of red chili). Jurnal AGRIFOR Vol XII No1. ISSN : 1412 $-6885.22-29$.

Annabi, M., Houot, S., Francou, F., Poidrenaud, M., \& Le Bissonnais, Y. (2007). Soil aggregate stability improvement with urban composts of different maturities. Soil Science of American Journal 71 : 413-423.

Arifin, Z., \& Tabrani, G. (2014). Pewarisan sifat agronomi tanaman cabai (Capsicum annuum 
L.) toleran di lahan gambut (Inheritance agronomic properties of the chili plant (Capsicum annuum L.) peatlands tolerant). Jurnal Online Mahasiswa (JOM) Bidang Pertanian, 1(1), 1-10.

Ashrafuzzaman, M., Halim, M. A., Ismail, M. R., Shahidullah, S.M., \& Hossain M. A. (2011). Effect of plastic mulch on growth and yield of chilli (Capsicum annuum L.) Braz. Arch. Biol. Technol. V.54 n.2: pp. 321-330.

Brinton, W.F. (2000). Compost Quality, Standard and Guideline. Woods End Research Laboratory, Inc.

California Compost Quality Council. (2001). Compost Maturity Index. California Compost Quality Council. Nevada City, CA 95959.www.ccqc.org.

Canet, R. \& Pomares F.(1995). Changes in physical, chemical and physico-chemical parameters during the composting of municipal solid wastes in two plants in Valencia. Bioresource Technology 51, 259-264.

Carter, M. R. (2002). Soil quality for sustainable land management: organic matter and aggregation interactions that maintain soil functions. Agronomy Journal, 94, 38ñ47.

Casado-Vela, J., Selle 's, S., Navarro, J., Bustamante, M. A. Mataix, J., Guerrero, C., \& Gomez, I. (2006). Evaluation of composted sewage sludge as nutritional source for horticultural soils. Waste Management 26 946-952, www.elsevier. com/locate/wasman.

Cuhna-Queda, A. C., Ribeiro, H. M., Ramos, A., \& Cabral, F. (2007). Study of biochemical and microbial paramaters during composting of pine and eucalyptus bark. Bioresour technol 98: 3213-3220.

Esteban, E., Moreno E., Pe nalosa, J., Jos' e I. Cabrero, Mill' an, R., \& Zornoza, P. (2008). Short and long-term uptake of $\mathrm{Hg}$ in white lupin plants: kinetics and stress indicators. Environmental and Experimental Botany 62 (2008) 316-322,

Farrell, M., \& Jones, D. L. (2009). Critical evaluation of municipal solid waste composting and potential compost markets. Bioresources Technology 100, 4301-4310.

Francou, C., Poitrenaud, M., \& Houot, S. (2005). Stabilization of organic matter during composting: influence of process and feedstocks. Compost Science \& Utilization, Vol. 13, No 1, 72-83.

Hafis, S.M., Ridzuan, M. J. M., Mohamed, A.R., Farahana, R. N., \& Syahrullail, S. (2014). An experimental investigation of palm pressed fibre waste as lubricant in strip drawing. $J$. Teknologi. 66: 3, 91-98. eISSN 2180-3722.

Huang, G., Zhong, L., Zhang, Z., \& Wu, Q. (2003). Physicochemical changes and maturity evaluation of solid organic waste compost. Ying Yong Sheng Tai Xue Bao. May:14(5):813-8.

Huang, G.F., Wu, Q.T., Wong, J.W.C., Nagar, B.B. (2005). Transformation of organic matter during co-composting of pig manure with sawdust. Bioresource Technology 97 (2006) 1834-1842. doi:10.1016/j. biortech.2005.08.024

IPRI (Indonesian Palmae research Institute). (2010). Utilization of oil palm fibera shells as a silica source alternative. http://balitka. litbang.pertanian.go.id/

Irshad, M., Eneji, A. E., Hussain, Z., \& Ashraf, M. (2013). Chemical characterization of fresh and composted livestock manures. Journal of Soil Science and Plant Nutrition, 13(1), 115-121

Irsyad, M., Sikanna, R., Musafira. (2014). Translokasi merkuri (Hg) pada daun tanaman bayam duri (Amaranthus spinosus L) dari tanah tercemar (Translocation of mercury $(\mathrm{Hg})$ in the leaves of spinach thorns 
(Amaranthus spinosus L) from contaminated soil). Online Jurnal of Natural Science, Vol.3(1): 8-17, ISSN: 2338-0950 2014.

Ismail, M. H. S., Haddadian, Z., \& Shavandi, M. A. (2012). Process simulation and optimation of palm oil waste combution using aspen plus. Research Journal in Engineer and Applied Sciences 1 (5) 266273 (ISSN:2276-8467).

Jensen, A., et al.(1998). TG-FTIR study of the influence of potassium chloride on wheat straw pyrolysis. Energy Fuels, 12 (5), 929938.

Johnson, J. M., Hough-Goldstein, J. A. \& Vangessel, M. J. (2004). Effects of straw mulch on pest insects, predators, and weeds in watermelons and potatoes. Environ. Entomol. 33, 1632- 1643.

Kraus, P. \& Grammel, U. (1992). Die Relevanz der Schadstoffdiskussion bei der Bioabfallko-mpostierung. (Relevance of contaminant discussion for bio-waste composting) in Abfallwirtschaft 9, MIC Baeza-Verlag Kassel

Kumar V. R. S., Sivakumar, K., Purushothaman M.R., Natarajan, A., \&Amanullah, M.M. (2007). Chemical changes during composting of dead birds with caged layer manure. Journal of Applied Sciences Research, 3(10): 1100-1104

Lahuddin. 2007. Aspek unsur mikro dalam kesuburan tanah (Aspects of micro elements in soil fertility). Pidato Pengukuhan Guru Besar. Universitas Sumatera Utara. Medan

Mckinley, V. L. \& Vestal, R. J. (1985). Physical and chemical correlates of microbial activity and biomass in composting municipal sewage sludge. Appl Environ Microbiol, 50 1395-1403.

Montejo C., Costa, C., \& Marquez, M. C. (2015). Influence of input material and operational performance on the physical and chemical properties of MSW compost. Journal of Environmental Management Volume 162, 1 October 2015, Pages 240249. doi:10.1016/j.jenvman.2015.07.059

Nagasaki, K., Shoda, M., \& Kubota, H. (1985). Effect of temperature composting of sewage sludge. Applied and Environmental Microbiology 50, 1526-1530.

Ndegwa, P. M., Thompson, S. A., \& Das, K. C. (2000). Effect of stocking density and feeding rate on vermicomposting of biosolids. Bioresour Technology 715-12.

Nopriani, L. S. (2011). Teknik uji cepat untuk identifikasi pencemaran logam berat tanah di lahan apel Batu (Rapid testing techniques for the identification of heavy metal pollution of soil from apple cultivation in Batu regency). Disertasi Fakultas Pertanian.Universitas Brawijaya. Malang Pan, I. \& Sen, S. K. (2013). Microbial and Physico-chemical analysis of composting process of wheat straw. Indian Journal of Biotechnology. Vol 12, January 120-128.

Pan, I., Dam, B., \& Sen S. K. (2012). Composting of common organic waste using microbial inoculants. Biotech 2: 127-134. [DOI : 10.1007/s13205-0110033-5]

Rincon, S. L. \& Gomez, A. (2012). Comparative behaviour of agricultural biomass residues during thermochemical processing. Global NEST Journal, vol. 14, no. 2, pp. 111-117

Schulze, E. D., Beck, E., \& Muller-Hohenstein, K. (2005). Plant Ecology. New York: Springer-Verlag Berlin Heidelberg.

Setyorini, D., Soeparto, \& Sulaeman. (2003). Kadar logam berat dalam pupuk (Levels of heavy metals in fertilizers). Prosiding Seminar Nasional Peningkatan Kualitas Lingkungan dan Produk Pertanian. Badan Litbang Pertanian. pp219-229

Shil, N. C., Naser, H. M., Brahma, S,. Yusuf, M. N. \& Rashid, M. H. (2013). Response 
of chilli (Capsium annuum L.) to zinc and boron application. Bangladesh J. Agril. Res. 38(1): 49-59 ISSN 0258-7122.

Sinkevičienè, A., Jodaugienè, D., Pupalienè, R. \& Urbonienè, M. (2009). The influence of organic mulches on soil properties and crop yield. Agronomy Research 7(Special issue I), 485-491.

Sǿnsteby, A., Nes, A. \& Måge, F. (2004). Effects of bark mulch and NPK fertilizer on yield, leaf nutrien status and soil mineral nitrogen during three years of strawberry production. Acta. Agric. Scand. Sect. B, Soil and Plant $54,128-134$.

Standar Nasional Indonesia (Indonesian Standard of Compost) SNI 19-7030-2004. Spesifikasi kompos dari sampah organik domestic (Compost specification from domestic organic waste). ICS 13.030.40. Badan Standardisasi Nasional.

Stoffella, P. J. \& Kahn, B. A. (2001). Compost utilization in horticultural cropping systems. CRC Press - Technology \& Engineering 432 pages

Sudiyani, Y., Setyarini, D., Triwahyuni, E., Sudiyarmanto, Sembiring, K. C., Aristiawan, Y., Abimanyu, H., \& Han, M. H. (2013). Utilization of biomass waste empty fruit bunch fiber of palm oil for bioetanol production using pilot-scale unit. Energy Procedia 32(31-38).

Sundh, I., \& Ronn, S. (2002). Microbial succession during composting of sourceseparated urban organic household waste under different initial temperature conditions. In: Insam H, Riddech, N., Klammer, S. (eds) Microbiology of composting. SpringerVerlag. Berlin Heiselberg, pp 53-64.

Susana, R., \& Suswati, D. (2011). Ketersediaan $\mathrm{Cd}$, gejala toksisitas dan pertumbuhan 3 spesies Brassicaceae pada media gambut yang dikontaminasi kadmium $(\mathrm{Cd})(\mathrm{Cd}$ availability, symptoms of toxicity and the growth of three species of Brassicaceae in peat media contaminated by cadmium $(\mathrm{Cd})$. Jurnal Perkebunan dan Lahan Tropika 1:9-16

Thiam, L. C., \& Bhatia, S. (2008). Catalytic processes towards the production of biofuels in a plam oil and oil palm biomass-based biorefinary. Bioresource Technology 99: 7911-7922.

Tiquia S.M. (2005). Microbiological parameters as indicators of compost maturity. Journal of Applied Microbiology Volume 99, Issue 4, pages 816-828, October 2005 DOI: 10.1111/ j.1365-2672.2005.02673.x

Topan, M. (2008). Panduan Lengkap Budi Daya dan Bisnis Cabai (Complete Cultivation Guide and Business of Chili). Agromedia Pustaka. Jakarta. 190 hal.

USDA-NRCS. (2000). United States Department of Agriculture-Natural Resources Conservation Service. Composting: Environmental Engineering National Engineering Handbook. 637. www.info.usda.gov/CED/ftp/CED/neh637ch02.pdf.

Vázquez, M.A., de la Varga, D., Plana, R., \& Soto, M. (2015). Integrating liquid fraction of pig manure in the composting process for nutrient recovery and water re-use. Journal of Cleaner Production, Volume 104, 1 October 2015, Pages 80-89

Venglovsky, J., Sasakova, N., Vargova, M., Pacajova, Z., Placa, I., Petrovsky, M., \& Harichova, D. (2005). Evolution of temperature and chemical parameters during composting of pig slurry soilid fraction amended with natural zeolite. Bioresources Technology 96, 181-189.

Widyati. (2011). Potensi tumbuhan bawah sebagai akumulator logam berat untuk membantu rehabilitasi lahan bekas 
tambang (Potential of herb stratum plants as accumulators of heavy metals to help the rehabilitation of mined land). Jurnal Mitra Hutan Tanaman. Vol $6: 2$ (46-56).

Yanti, Y., Gustian, \& Rahma, H. (2009). Aplikasi agen hayati Pseudomonas fluorescens sebagai penginduksi ketahanan untuk meningkatkan produksi tanaman cabai terhadap penyakit virus kuning di Kecamatan Kuranji Kotamadya Padang (Application of biological agents Pseudomonas fuorescens as resistance inducers to increase the production of chili against yellow viral diseases in Kuranji district, Padang Regency). Warta Pengabdian Andalas Volume XV, Nomor 22, 46-57.

Yusoff. S. (2006). Renewable energy from palm oil-innovation of effective utilization of waste. Journal of Cleaner Production 14: 87-93.

Zmora-Nahum, S., Markovitch, O., Tarchitzky, J. $\&$ Chen, Y. (2006). Dissolved organic carbon (DOC) as a parameter of compost maturity. Soil Biology and Biochemistry Volume 37, Issue 11, November 2005, Pages 2109-2116. doi:10.1016/j.soilbio.2005.03.013

\section{Policy Brief}

Processing of oil palm empty fruit bunches into compost must be improved. In addition to dealing with the waste, composting also serves to empower communities around the mills. In addition, it is necessary for the introduction to the community around the palm oil mills that compost palm bunches can be utilized in horticultural crops. 